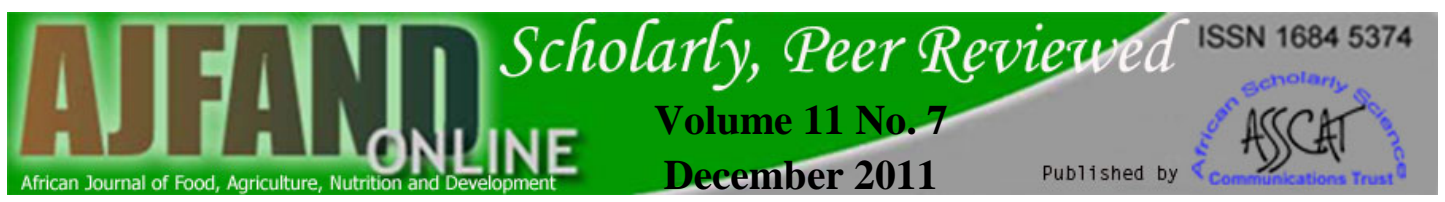

\title{
EFFECTIVENESS OF PLANT BASED INSECTICIDES AS A SUSTAINABLE MEANS OF CONTROL OF CUCUMBER MOSAIC VIRUS
}

$$
\text { Khan MA }{ }^{1} \text {, Mahmood } \mathrm{Y}^{1^{*}} \text { and } M \text { Shafque }{ }^{1}
$$

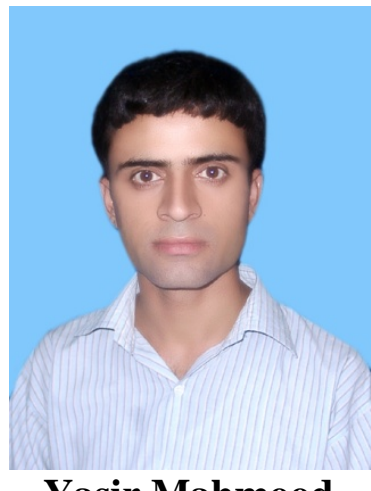

Yasir Mahmood

*Corresponding author’s email: yasir_scout@yahoo.com

${ }^{1}$ Department of Plant Pathology, Faculty of Agriculture, University of Agriculture Faisalabad, Pakistan. 
ABSTRACT

Cucumber (Cucumis sativus) is an important crop in Pakistan. It is affected by many biotic and abiotic factors. Among these, Cucumber mosaic virus is the important disease with economic losses. The purpose of this study was to evaluate the effectiveness of plant based insecticides as a sustainable means to control the Cucumber Mosaic Virus. Sustainable means are economical, environmental friendly and socially acceptable. For this purpose, cucumber varieties /lines were evaluated against cucumber mosaic virus (CMV) under natural field conditions conducive for development of disease and aphid population. All varieties/lines were in the range of moderately susceptible to susceptible except Beet alpha and Nandini-732 which were moderately resistant with $16.26 \%$ disease incidence and highly susceptible with $50.11 \%$ disease incidence respectively. Relative humidity and rainfall had a positive relationship with the disease (CMV) development while temperature had a negative relation with disease development. Aphid population increased with the increase of relative humidity and rainfall and decreased as the humidity and rainfall decreased. With the increase in temperature, there was a gradual decrease in aphid population build up. For economical and environmentally safe management of the disease, one pesticide and different bio-pesticides were evaluated under natural field conditions against insect vector and disease. In order to manage CMV and aphid population, the pesticide Imidacloprid and three plant extracts of neem (Azadirachta indica), garlic (Calotropis gigantea) and aak (Allium sativum) were used. All the applied treatments gave significant results. Among them, imidacloprid was proved the best in reduction of disease incidence/severity and aphid population. It was followed by neem, garlic and aak extract respectively. Aak was found to be the least effective treatment even though it led to a significant reduction in disease incidence and aphid population compared to the untreated control where maximum plant infection and aphid population was found on plants.

Key words: Cucumber, aphid, Environmental conditions, imidacloprid 


\section{INTRODUCTION}

Cucumber originated in India and large genetic varieties have been observed in different parts of the country. It has been cultivated for at least 3,000 years in Western Asia and was probably introduced to other parts of Europe by the Romans. Records of cucumber cultivation appeared in France in the 9th century, England in the 14th century and in North America by the mid-16th century. It is grown for its fruits, which are eaten fresh or pickled in most countries, but which are also eaten fried (usually when fruits have been harvested at a more mature stage). Fresh cucumbers are sliced and served in salads or as garnishes to add color to meals. They are served and eaten at home and in restaurants (especially fast food establishments) where pickle chips or relish are served on hamburgers and hot dogs. Pickles are also served as appetizers. Cucumber fruits provide mostly water as well as some vitamin A and C and it is the ideal food for people having trouble with body weight, because it contains mostly water, some fiber, and few calories. It also has medicinal value for human beings. Cucumber is also among 35 fruits, vegetables, and herbs identified by the National Cancer Institute as having cancer-protective properties. In regards to the nutritional composition of cucumber, a 100 g edible portion contains water $96 \%$, calcium $14 \mathrm{mg}$, potassium $17 \mathrm{mg}$, sodium $2 \mathrm{mg}$, thiamine $0.03 \mathrm{mg}$, riboflavin 0.02 mg, niacin $0.30 \mathrm{mg}$, ascorbic acid $4.7 \mathrm{mg}$, fats $0.1 \mathrm{~g}$, carbohydrate $2.9 \mathrm{~g}$, fiber $0.6 \mathrm{~g}$, protein $0.5 \mathrm{~g}$, vitamin $45 \mathrm{IU}$ and vitamin B6 $0.05 \mathrm{mg}$. This $100 \mathrm{~g}$ portion provides 13 kcal energy [1].

A total area of 1108 hectares with an average production of 5.85 ton ha ${ }^{-1}$ and with a total production of 6487 tons was recorded in Pakistan in 2005-06 [2]. Although it is one of the major vine crop grown in this country, the yields are quiet low. Increase in cucumber production can be achieved by either bringing more area under its cultivation or by adopting improved varieties and better cultural practices. Viruses badly effect cucurbit cultivation on a worldwide basis. The important viruses of cucurbitaceae family are Zucchini yellow mosaic virus (ZYMV), Water melon mosaic virus (WMV), Papaya ring spot virus (PRSV), Cucumber green mottle mosaic virus (CGMMV), Cucumber mosaic virus (CMV), Melon necrotic spot virus (MNSV). Among these viruses, CMV is the most important virus having a very wide host range. CMV has a wide range of hosts and attacks a great variety of vegetables, ornamentals, and other plants (as many as 191 host species in 40 families). Among the most important vegetables affected by cucumber mosaic are peppers (Capsicum annuum L.), cucurbits, tomatoes (Lycopersicon esculentum Mill.), and bananas (Musa L. spp.). Cucumbers infected with cucumber mosaic may have a bitter taste and make soggy pickles [3].

Aphids transmit more than 80 kinds of viral diseases, including banana mosaic, papaya mosaic, papaya ring spot, citrus tristeza and passion fruit woody virus. CMV is transmitted primarily by aphids, and also by seed, cucumber beetles, parasitic plants, humans and mechanically. It is transmitted by more than 60 species of aphid, notably Aphis gossypii and Myzus persicae, in the non-persistent manner and is readily transmissible through plant sap.

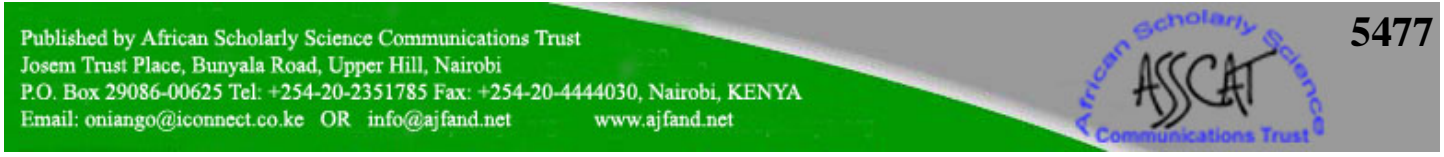




\section{MATERIALS AND METHODS}

The experiment was conducted in the area of Department of Plant Pathology, University of Agriculture, Faisalabad, Pakistan during the summer session of 2009 from February to May. Seeds of 12 varieties/hybrid lines (Fresco, Shaheen, Nandini732, EL-Karim, Baran-180, Kukunis-582, Beit alpha, Tyrandad, Happy, Padmini, Desi and Pico) of cucumber were obtained from market and Ayub Agriculture Research Institute Faisalabad. Each variety was sown in two non-replicated rows on a bed 1 meter wide and 13 meter long with plant-to-plant distance of $30-35 \mathrm{~cm}$, bed to bed spacing $30 \mathrm{~cm}$. A single row of susceptible check was repeated after every third variety to serve as a spreader of CMV. It was also sown at the border on all four sides. The level of susceptibility and resistance of cucumber varieties/hybrid lines against CMV was calculated by counting the number of plants infected in each variety and the disease incidence was calculated from the following formula

$$
\text { Disease Incidence }=\frac{\text { Number of infected plants }}{\text { Total number of plants }} \text { X } 100
$$

The level of susceptibility/resistance in different varieties/lines of cucumber was graded according to the disease rating scale [4]. Data of environmental factors such as maximum and minimum temperature, relative humidity were obtained during the growth period of the crop from the Department of Crop Physiology, University of Agriculture, Faisalabad. The experiment was conducted in randomized complete block design with three replications. This data were taken on weekly basis for four varieties. The data of aphid population were recorded. Three plants in each row were selected at random and the population of aphid was recorded from upper, middle and lower leaves. For the evaluation of three plant extracts and one pesticide for the management of the disease, an experiment was conducted in the pots under completely randomized design with three replications. Treatments applied were $\mathrm{T}_{1}=$ Imidacloprid (Confidor), $\mathrm{T}_{2}=$ Neem extract (Azadirachta Indica) $\mathrm{T}_{3}=$ Aak extract (Calotropis Gigantea), $\mathrm{T}_{4}=$ Garlic extract (Allium Sativum) and $\mathrm{T}_{5}=$ Control randomly to each block of cucumber varieties. Imidacloprid was applied at 600 gm/acre. While neem, aak and garlic extracts were sprayed on these plants at $1 \%$ and $2 \%(\mathrm{v} / \mathrm{v})$ concentration [5]. The control group was not sprayed with any chemical or plant extract. A small spraying instrument was used to spray the cucumbers every week for three weeks. Data regarding the disease incidence and aphid population was recorded before and after the disease appearance. All the CMV and aphid population CMV as influenced by biocontrol product application was statistically analyzed. All possible interactions were determined through ANOVA and the treatment means was compared by LSD test at 5\% level of probability [6].

\section{RESULTS}

Most of the varieties fall in susceptible range except Beit Alpha which was MR at $16.26 \%$. Nandini-732 was found to be highly susceptible to disease incidence. Fresco, Shaheen, El-karim, Baran-180 and pico were the susceptible varieties while

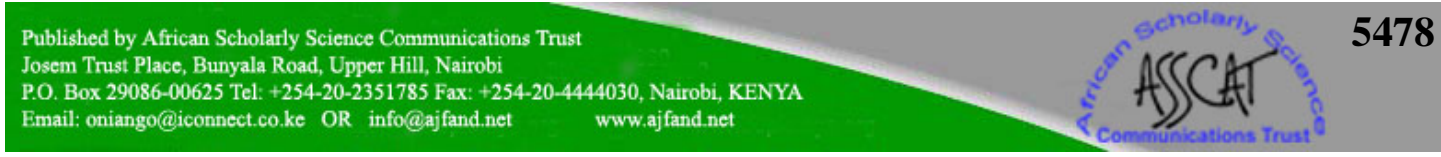


Kukunis-582, Happy, Tyrandad, Padmini and Desi were moderately susceptible (Table 1).

Regarding CMV infection, the individual effects of varieties, treatments and dates at disease incidence were highly significant. Two way interactions of date, varieties and date, treatments were non-significant, while that of varieties/treatments was significant. Three way interactions of dates, varieties and treatments also showed nonsignificant results. Such results indicate that CMV-infection differed by dates, treatments and varieties. All the dates, varieties and treatments were also significantly different from each other.

According to the data collected, disease was shown to progress continuously after the second date. Maximum percent plant infection was found at first date while, minimum percent plant infection was found at $2^{\text {nd }}$ date of data collection, that was increased on $3^{\text {rd }}$ and $4^{\text {th }}$ date respectively. V2 (Happy) was the most susceptible variety showing 31.35\% infection followed by V1, V3 and V4 with 27.25, 24.57 and 20.18 percent infection respectively. Minimum percent plant infection was found on T1, which was the most effective treatment. Maximum percent infection was found on untreated control.

The percent infection recorded on all five treatments showed that imidacloprid was the most effective followed by neem extract, garlic and aak extract which was least effective (Table. 2). Regarding CMV infection, the individual effects of varieties and treatments were significant.

The results indicated that the disease incidence varied with variety of cucumber and the treatment employed. The percentage plant infection on all the treatments was 31.17, 26.33, 24.88, 23.85 and 22.96 with Imidacloprid, Neem, Aak, Garlic and Control respectively (Table 2). The data showed that the comparative effect of all treatments was significant with percent plant infection. Imidacloprid was best to minimize the \% infection at 22.96 followed by neem extract 23.85; garlic extract 24.88 and AAK extract which showed a minimum control over the disease. Maximum disease incidence was found on untreated control. Regarding aphid population the individual effects of varieties, treatments and dates and their interaction effects were highly significant. Two way interactions of dates, varieties and treatments were nonsignificant, while that of dates/treatments was significant. Three way interactions of dates, varieties and treatments also showed non-significant results. These results show that the vector differs at different dates, varieties and treatments. All the dates, varieties and treatments differed significantly from each other.

Minimum aphid population was found on Padmini and EL-Karim which were statistically at highest parameter. The aphid population decreased on $2^{\text {nd }}$ date then increased on $3^{\text {rd }}$ and $4^{\text {th }}$ date gradually. The aphid population recorded on all four varieties is given by 3.33, 3.46, 2.70, and 2.78 on EL-Karim, Happy, Padmini and pico respectively (Table 3). Minimum aphid population was found with imidacloprid signifying that it was the most effective treatment while maximum aphid population was found on untreated control. The aphid population recorded in all five treatments

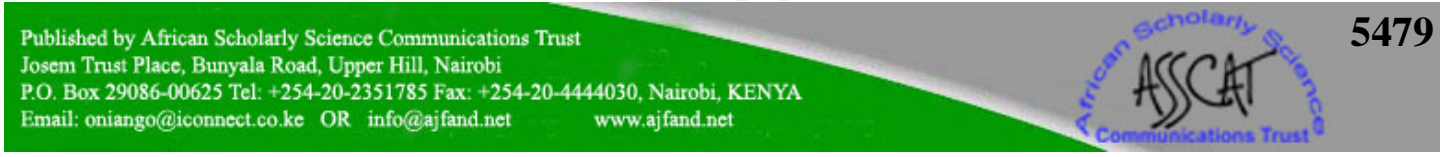




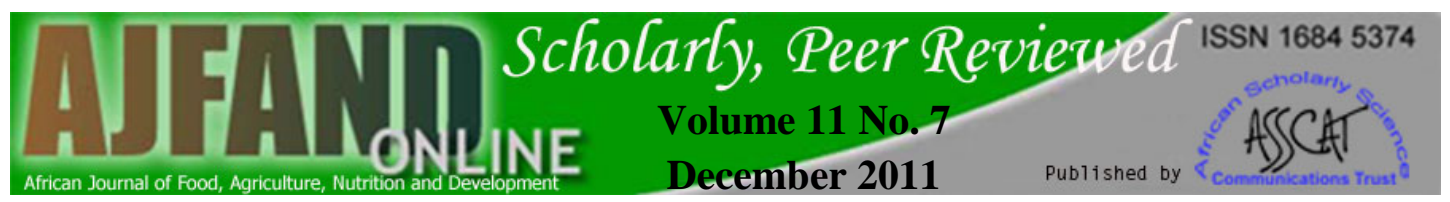

showed that imidacloprid was followed by neem extract, garlic and aak extract which was least effective. The results indicated that the aphid population was different at different varieties and treatments. The aphid population on all the treatments was 1.77, 2.83, 3.40, 2.94 and 3.77 with Imidacloprid, neem, aak, garlic and control respectively. Padmini and Pico showed the minimum number of aphids while maximum population was observed on Happy followed by EL-Karim (Table 3). The table shows that the effect of all the treatments differs significantly. All the treatments showed positive control over the aphid population while untreated sample showed maximum aphid population. Aak extract was the least effective treatment 3.40 aphids followed by garlic 2.94 aphids, neem extract 2.83 aphids and imidacloprid 2.06 aphids respectively. The relationship of maximum temperature, minimum temperature and relative humidity with percent plant infection for all four varieties was best explained by linear regression and represented graphically. Environmental temperature had significant correlation with percent plant infection of CMV on all four varieties. The rate of percent plant infection decreased with the increase in temperature from 33$40^{\circ} \mathrm{C}$. This relationship of percent plant infection with temperature was best explained by linear regression models as indicated $-0.98,-0.98,-0.96$ and -0.96 values respectively in four varieties. The effect of maximum temperature with percent plant infection was also negative (Fig. 1). A significant correlation was found between percent plant infection and humidity. Percent plant infection increased with increase in humidity. This relationship of percent plant infection with relative humidity was best explained by linear regression models as indicated by high values of correlation co-efficient such as $0.97,0.97,0.97$ and 0.95 values respectively in four varieties. The effect of relative humidity with percent plant infection was positive (Fig. 2). Rain fall had a very little impact on the disease incidence or the effect might be negligible (Fig. 3). 


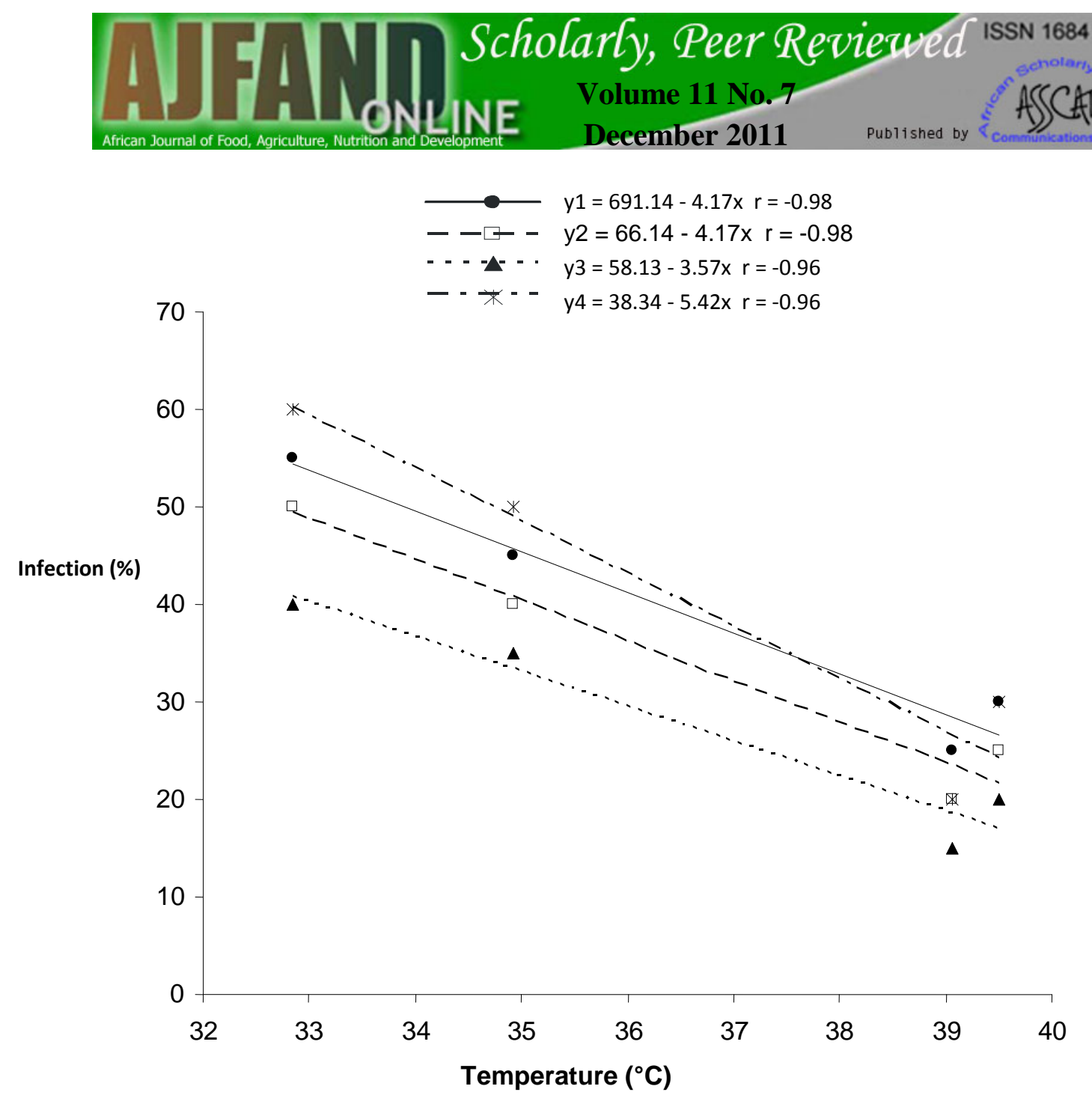

Figure 1: Graph depicting relationship between temperature and plant infection (\%) for varieties: $\mathrm{y} 1$ = El-Karim, $\mathrm{y} 2$ = Happy, $\mathrm{y} 3$ = Padmini and y4 = Pico. 


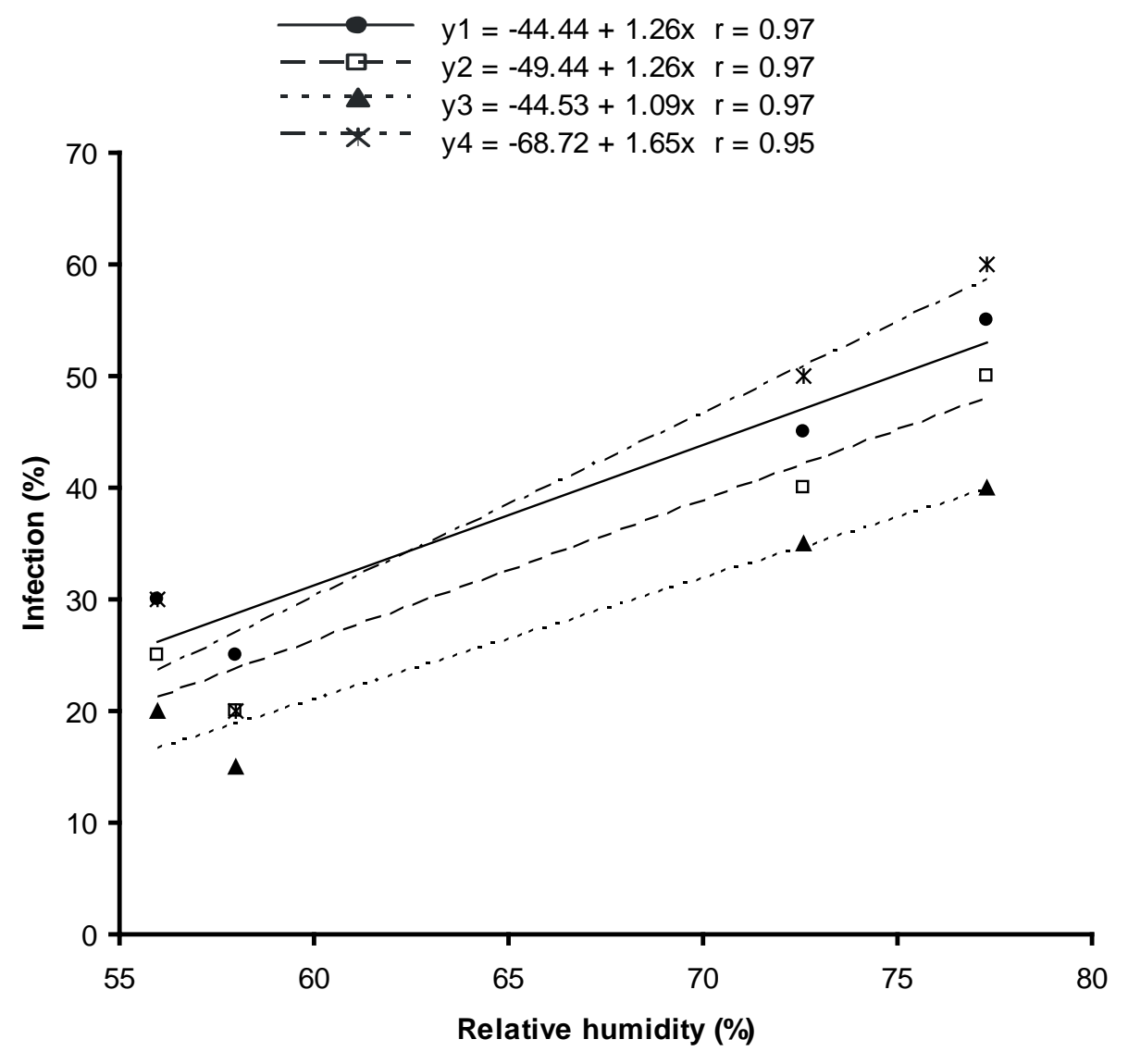

Figure 2: Graph of Relationship of relative humidity with percent plant infection for varieties y1 = El-Karim, y2 = Happy, y3 = Padmini and y4 = Pico. 


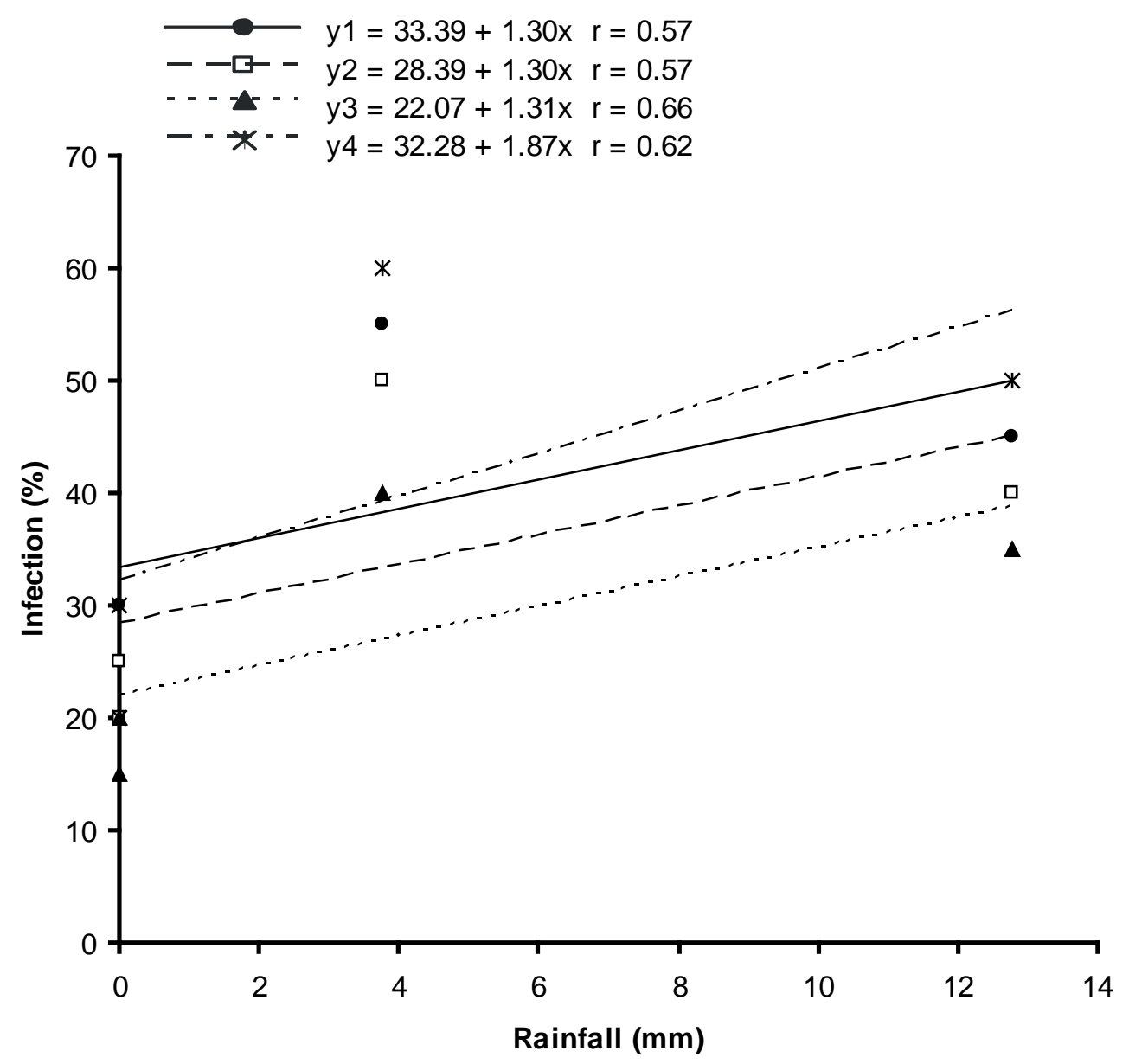

Figure 3: Graph showing Relationship of rainfall with disease incidence for varieties y1 = El-Karim, y2 = Happy, y3 = Padmini and y4 = Pico.

The percentage aphid population decreased with increase in temperature (Fig. 4, Fig.5). While rain fall and relative humidity developed a positive relationship with the aphid population build up (Fig. 6, Fig.7). 


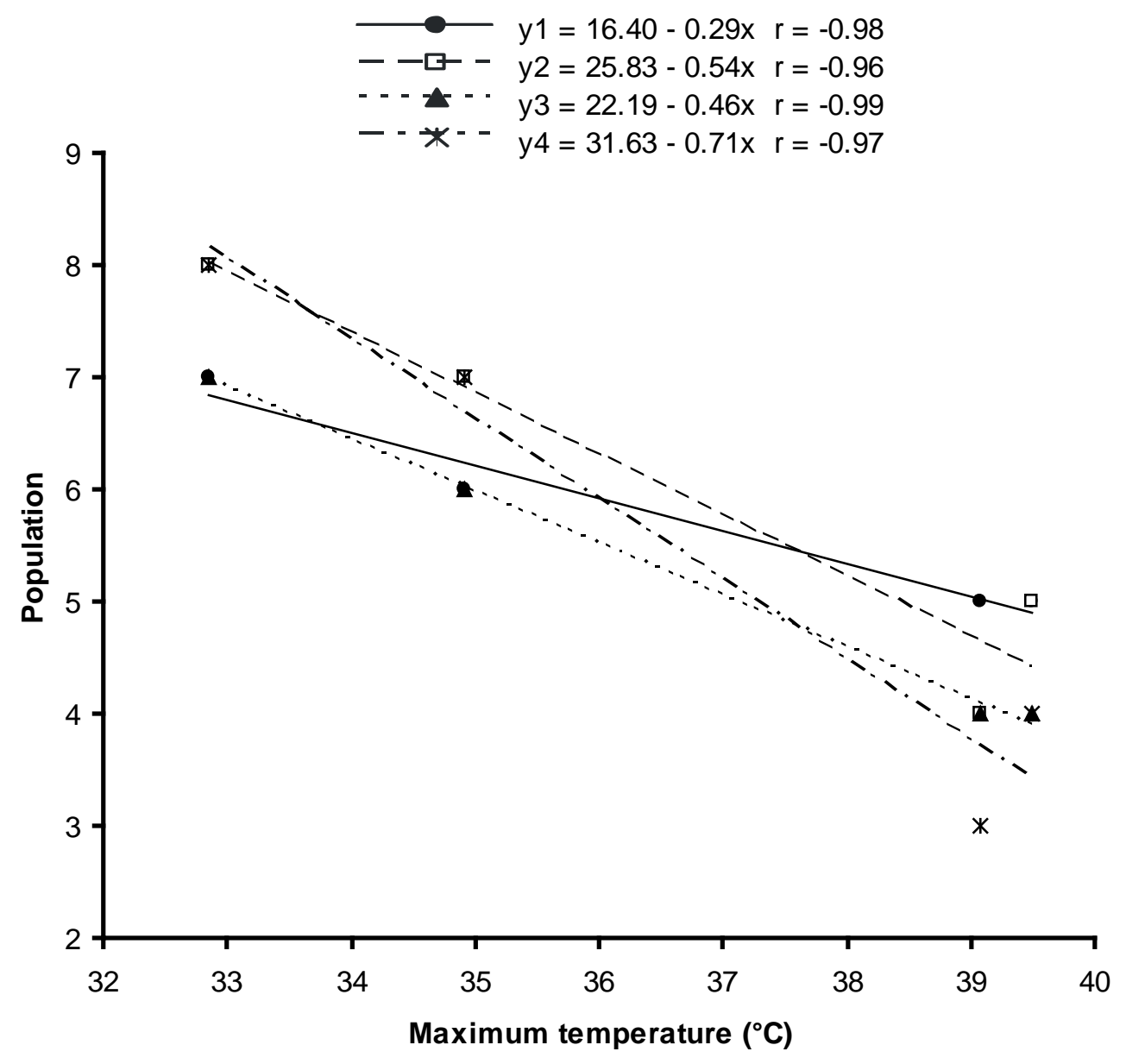

Figure 4: Relationship of maximum temperature with aphid population for varieties y1 $=$ El-Karim,$\quad$ y2 $=$ Happy, y3 $=$ Padmini and y4 $=$ Pico. 


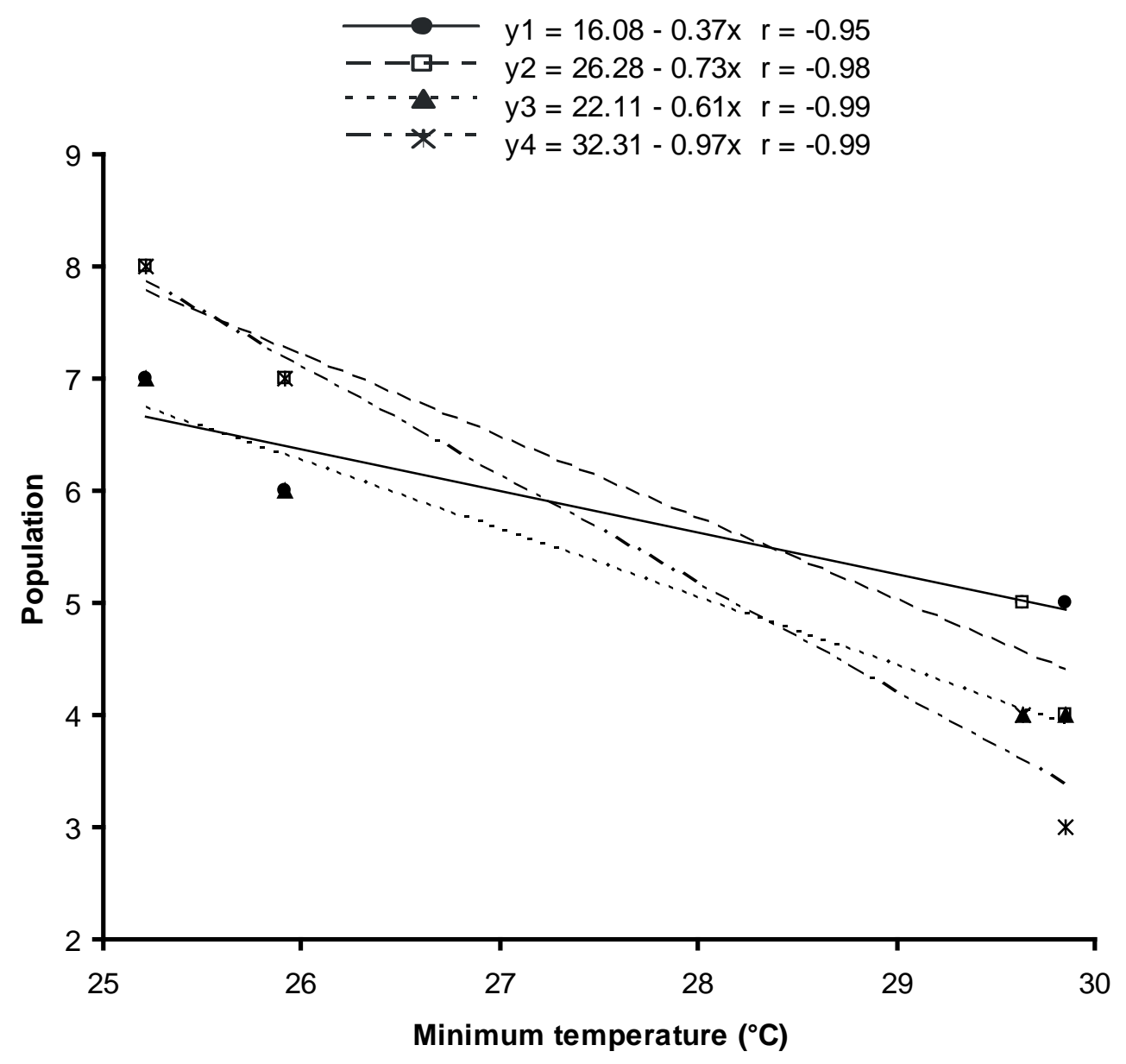

Figure 5: Relationship of minimum temperature with aphid population for varieties y1 = El-Karim, y2 = Happy, y3 = Padmini and y4 = Pico. 


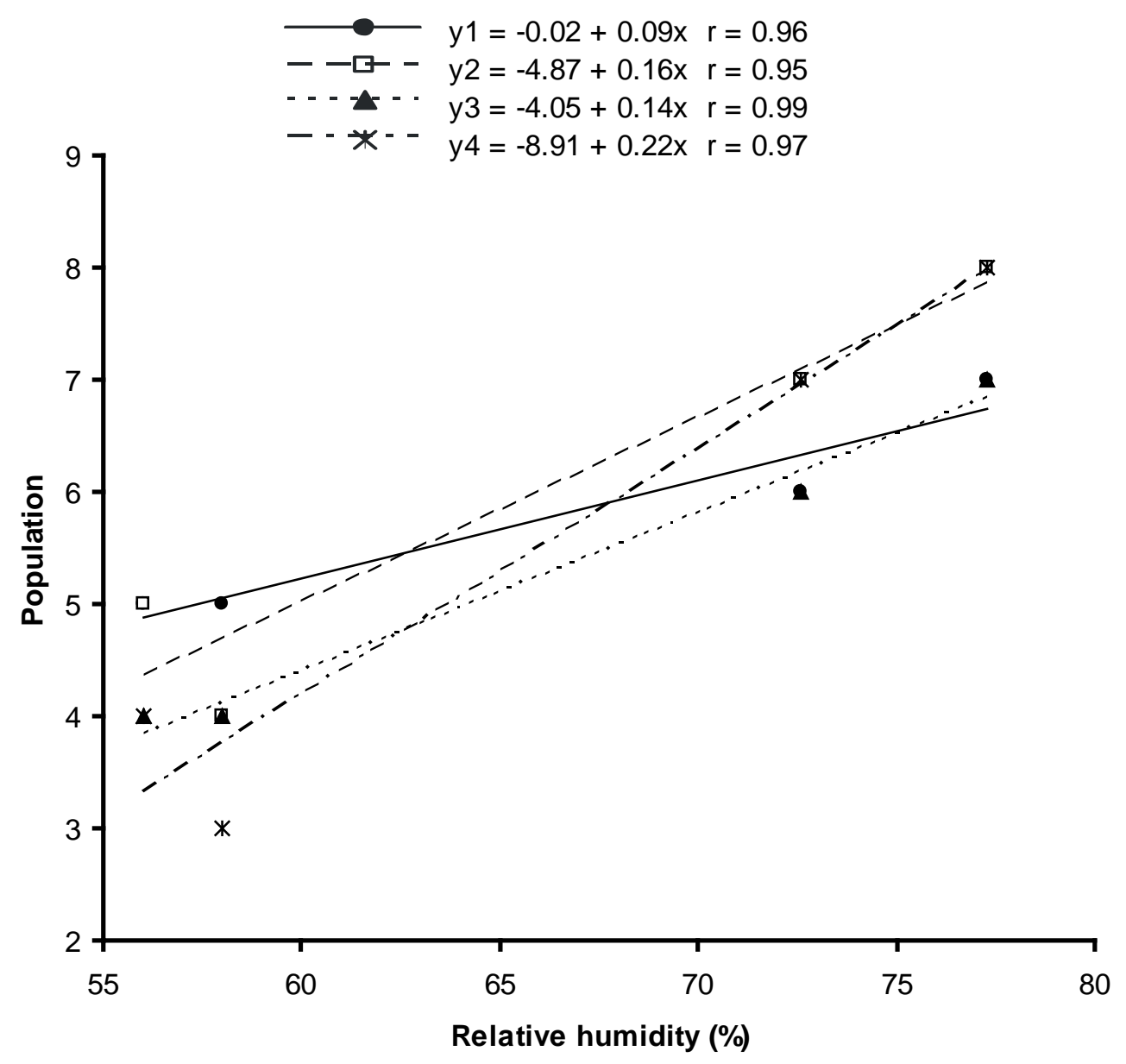

Figure 6: Relationship of relative humidity with aphid population for varieties y1 = El- Karim, Y2 = Happy, y3 $=$ Padmini and y4 $=$ Pico. 


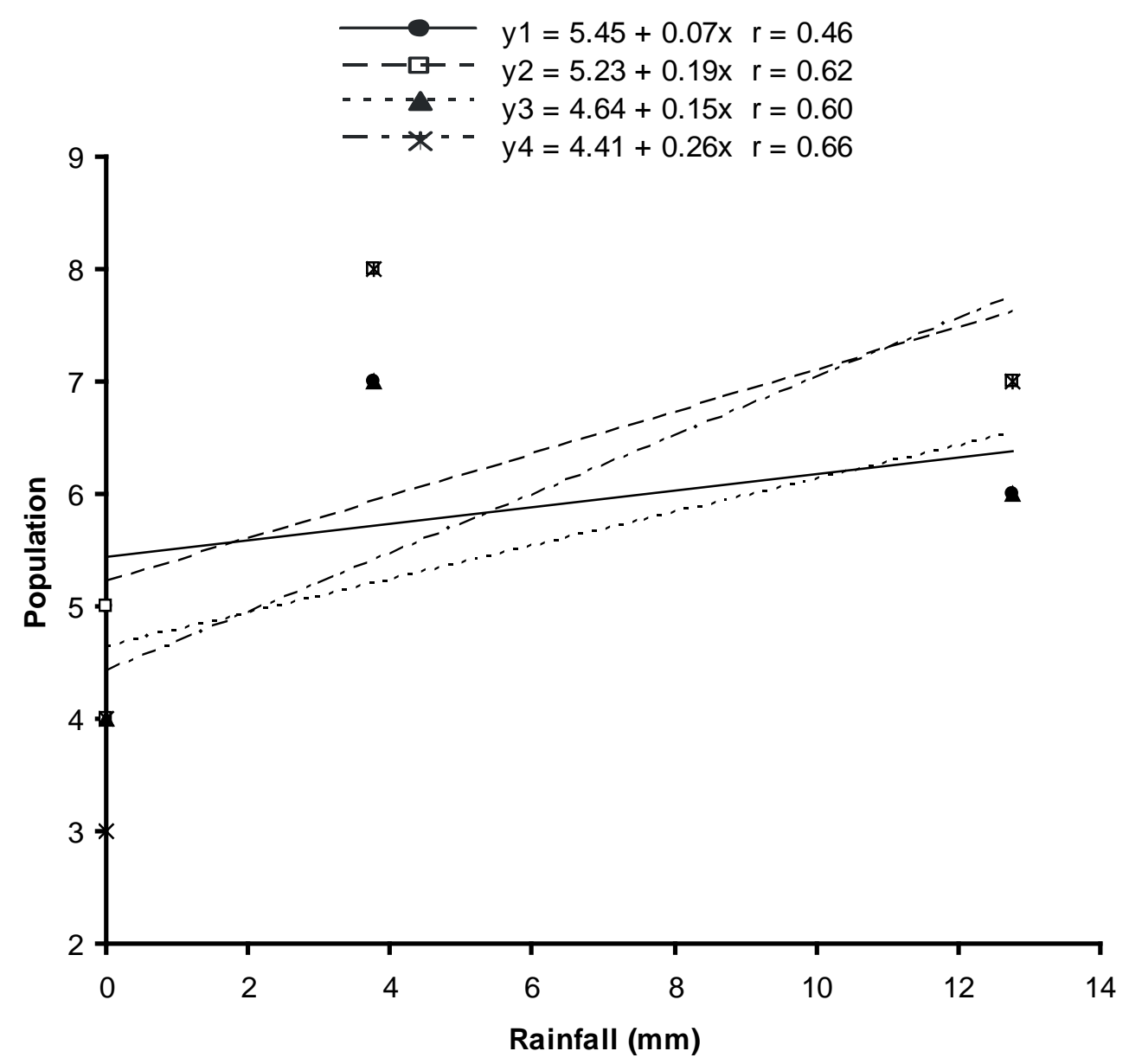

Figure 7: Relationship of rainfall with aphid population for varieties y1 $=$ ElKarim, Y2 = Happy, y3 $=$ Padmini and y4 $=$ Pico.

\section{DISCUSSION}

Screening of cucumber varieties/lines against CMV was done to identify the resistance source. This helped in categorizing these varieties/lines as resistant, moderately resistant, moderately susceptible and susceptible. Those varieties/lines that showed resistance/tolerant response may be recommended against CMV. In a similar type of study, it was found that many cucumber varieties (Cucurnis sativus) were resistant to CMV and were generally not bothered by the other viruses [7]. Resistant varieties have been considered as the most efficient control of the plant diseases especially those caused by viruses [8]. Virus vector (aphid) played an important role in disease severity and incidence [9]. In 1991, a similar study found that probability of a single aphid transmitting the virus to the test plant was $50 \%$ and with 5 aphids per plant it was 100\% [10]. In 1973, it was reported that aphids (A. gossypli) successfully transmitted the viral disease [11]. The present study revealed that the comparative effect of all treatments was significant with percent plant infection. Imidacloprid was the best in minimizing the \% infection and aphid 
population build up followed by neem extract, garlic extract and aak extract respectively. In 2005, three products, Neem (Azadirachta indica) extracts, Effective Microbes (EM) and Imidacloprid were evaluated for their efficacy in the control of Bemisia tabaci and OYVMV on okra. Imidacloprid was proved to be best fallowed by neem extract [12]. In 1993 it was shown that imidacloprid is a well established insecticide being registered in more than 70 countries for foliar and soil application as well as seed treatment [13]. Chemically, imidacloprid belongs to the group of chioronicotinyls. In 1993, it was observed that imidacloprid is a systemic pesticide with physical/chemical properties that allow residues to move into treated plants and then throughout the plant via xylem transport and transiarninar (between leaf surfaces) movement. Residues of the insecticide then enter the target pest by ingestion or direct contact, disrupting the insect's nervous system by binding to postsynaptic, nicotinic acetylcholine receptors. The disruption of the nervous systems results in modified feeding behavior, paralysis, and subsequent death of the insect [14]. In a similar type of study in 2000, neem product (Phytopesticide FWB) efficacy was tested and compared with perfekthion (dimethoate) against sucking pests (jassid, aphid, thrips and whitefly) and satisfactory results was found [15]. In 1998, it was shown that use of imidacloprid (Imid+Oil treatment) effectively controlled the viral disease [16]. In 1994, it was found that Neem (Azadirachta indica) seed oil (NSO) applied to leaf discs at a concentration of $1.0 \%$ resulted in $94 \%$ to $100 \%$ mortality of second instar nymphs of currant-lettuce aphid [17]. In 1998, field experiments were conducted to evaluate the efficacy of three plant extracts, sacred basil (Ocimum sanctum), malbar nut (Adhutoda vesica), Chinese chaste tree (Vitex negudo) neem (Azadirachta indica) and synthetic insecticides (Endosulfan \& Carbaryl) and their combination products in controlling aphid, jassid, whitefly and fruit borers. All the treatments suppressed insect's population. The reduction in probing activity resulted in diminishing the probability of BYDV transmission by the aphids [18]. In 1994, Allium sativum (garlic) was successfully used to control fungal disease [19].

The present study revealed that as temperature was increased the disease incidence decreased and vice versa. The effect of relative humidity with percent plant infection was positive (Fig. 2) while the effect of rainfall on percent plant infection was negligible (Fig. 3). In a similar type of study in 2009, it was found that plant virus replication and spread require specific interactions between the obligate organism, the virus and its host. Both virus and plant factors, whether they are involved in virus accumulation or in defense against virus accumulation, require specific environmental conditions to maximize their activity. Temperature, light, moisture, air movement, soil status and plant nutrition were the major environmental factors that influenced virus accumulation in its host [20]. In 2008, it was observed that urdbean leaf crinkle viral disease showed overall significant correlation with maximum and minimum temperature and no correlation with relative humidity, rainfall and wind speed [21].

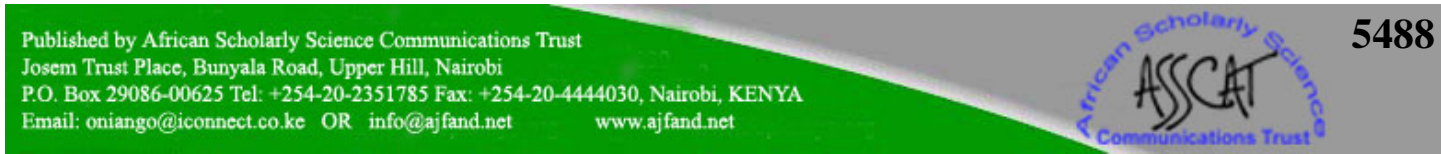




\section{CONCLUSION}

Present study revealed that finding resistant varieties is the only way to economically management of cucumber mosaic viral disease. However, the disease can be managed by understanding the environmental conditions. The disease can also be managed by using plant extracts and pesticides for example imidacloprid.

\section{ACKNOWLEDGEMENT}

This research was funded by Department of Plant Pathology, University of Agriculture, FSD, Pakistan. We gratefully acknowledge the supervision of Prof. Dr. M. Aslam Khan during the experiments. 


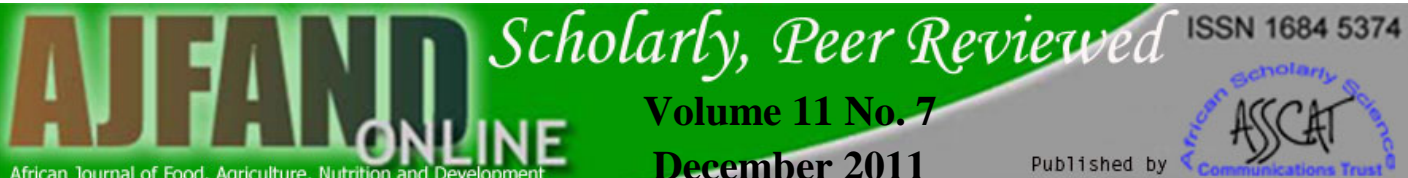 \\ December 2011

Table 1: Response of different varieties against CMV

\begin{tabular}{|c|c|c|c|}
\hline Sr. No. & Variety/Line & Means of Disease Ratings & $\begin{array}{l}\text { Level of Resistance/ } \\
\text { Susceptibility }\end{array}$ \\
\hline 1 & Fresco & 45.19 & S \\
\hline 2 & Shaheen & 41.25 & $S$ \\
\hline 3 & Nandini-732 & 50.11 & HS \\
\hline 4 & EL-Karim & 40.27 & $\mathrm{~S}$ \\
\hline 5 & Baran-180 & 37.51 & $\mathrm{~S}$ \\
\hline 6 & Kukunis-582 & 23.75 & MS \\
\hline 7 & Beit alpha & 16.26 & MR \\
\hline 8 & Tyrandad & 25.13 & MS \\
\hline 9 & Happy & 28.75 & MS \\
\hline 10 & Padmini & 27.50 & MS \\
\hline 11 & Desi & 26.25 & MS \\
\hline 12 & Pico & 40.11 & $\mathrm{~S}$ \\
\hline
\end{tabular}




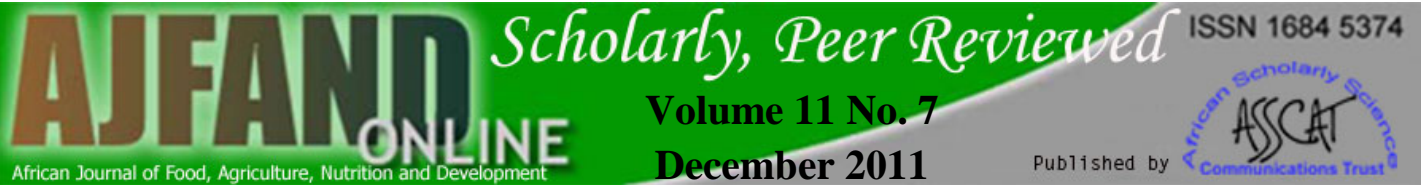

Table 2: Effect of treatment on disease incidence of four varieties and their respective means

\begin{tabular}{|c|c|c|c|c|c|}
\hline \multirow[b]{2}{*}{ Treatment } & \multicolumn{4}{|c|}{ Variety } & \multirow[b]{2}{*}{ Mean } \\
\hline & $\begin{array}{l}\text { EL-Karim } \\
\text { V1 }\end{array}$ & $\begin{array}{l}\text { Happy } \\
\text { V2 }\end{array}$ & $\begin{array}{l}\text { Padmini } \\
\text { V3 }\end{array}$ & $\begin{array}{l}\text { Pico } \\
\text { V4 }\end{array}$ & \\
\hline Imidacloprid & $25.42 \mathrm{gh}$ & 28.50 de & $20.75 \mathrm{ijk}$ & $17.17 \mathrm{l}$ & $22.96 \mathrm{D}$ \\
\hline Neem (Azadirachta Indica) & $25.75 \mathrm{fg}$ & $29.67 \mathrm{~cd}$ & $21.58 \mathrm{ij}$ & $18.42 \mathrm{kl}$ & $23.85 \mathrm{CD}$ \\
\hline AAK(Calotropis Gigantea) & $28.08 \mathrm{def}$ & $32.75 \mathrm{ab}$ & $24.92 \mathrm{gh}$ & $19.58 \mathrm{jkl}$ & $26.33 \mathrm{~B}$ \\
\hline Garlic (Allium Sativum) & $26.58 \mathrm{efg}$ & $31.17 \mathrm{bc}$ & $23.08 \mathrm{hi}$ & $18.67 \mathrm{kl}$ & $24.88 \mathrm{C}$ \\
\hline T5(Control) & 30.42 bcd & 34.67 a & $32.50 \mathrm{ab}$ & $27.08 \mathrm{efg}$ & $31.17 \mathrm{~A}$ \\
\hline Mean & $27.25 \mathrm{~B}$ & $31.35 \mathrm{~A}$ & $24.57 \mathrm{C}$ & $20.18 \mathrm{D}$ & \\
\hline
\end{tabular}

LSD value for Treatment $=1.186$, LSD value for Variety $=1.061$, LSD value for

Variety x Treatment $=2.372$

Table 3: Effect of treatments on aphid population on different varieties and their respective means

\begin{tabular}{|c|c|c|c|c|c|}
\hline \multirow[b]{2}{*}{ Treatment } & \multicolumn{4}{|c|}{ Variety } & \multirow[b]{2}{*}{ Mean } \\
\hline & $\begin{array}{l}\text { EL-Karim } \\
\text { V1 }\end{array}$ & $\begin{array}{l}\text { Happy } \\
\text { V2 }\end{array}$ & $\begin{array}{l}\text { Padmini } \\
\text { V3 }\end{array}$ & $\begin{array}{l}\text { Pico } \\
\text { V4 }\end{array}$ & \\
\hline T1(Imidacloprid) & 2.33 & 2.33 & 1.83 & 1.75 & $2.06 \mathrm{D}$ \\
\hline T2(Neem) & 3.25 & 2.83 & 2.58 & 2.67 & $2.83 \mathrm{C}$ \\
\hline ТЗ(AAK) & 3.75 & 3.67 & 3.08 & 3.08 & $3.40 \mathrm{~B}$ \\
\hline T4(Garlic) & 3.25 & 3.08 & 2.58 & 2.83 & $2.94 \mathrm{C}$ \\
\hline T5(Control) & 4.08 & 4.00 & 3.42 & 3.58 & $3.77 \mathrm{~A}$ \\
\hline Mean & $3.33 \mathrm{~B}$ & $3.46 \mathrm{~A}$ & $2.70 \mathrm{C}$ & $2.78 \mathrm{C}$ & \\
\hline
\end{tabular}

LSD value for Treatment $=0.206$, LSD value for variety $=0.185$ 


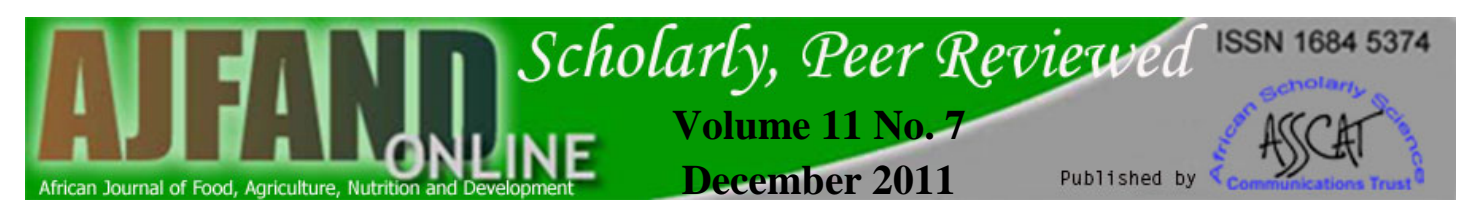

\section{REFERENCES}

1. Maynard D and N Donald Maynard Cucumber, Melons, and Watermelon. In The Cambridge World History of Food, edited by Kenneth F. Kiple and Kriemhild Coneè Ornelas. Cambridge, U.K.Cambridge University Press 2000: 2.

2. Anonymous Statistics of Pakistan, 2005-2006. Government of Pakistan, Ministry of Food, Agriculture and Live stock Division it is one of the most important summer vine vegetable crop (Economic Wing), Islamabad 2006.

3. Agrios GN Plant Pathology 5th Ed. Academic Press, U.S.A. 2005: 788-790.

4. Bashir $\mathbf{M}$ and $\mathbf{Z}$ Muhammad Identification of resistance in urdbean against two different viral diseases. Pak J Bot 2002; 34 (1): 49-51.

5. Hilje L, Stansly PA, M Carballo and GA Mora Repellency and deterrrency caused by plant extracts on B. tabaci adults. $3^{\text {rd }}$ Int. Bemisia Workshop. Barcelona. 17-20 Mar, 2003.

6. Steel Torrie JH and DA Dickie Principles and procedures of statistics. Abiometrical approach 3rd edition, 1997; 312-317.

7. Bernhardt E, Dodson $\mathbf{J}$ and $\mathbf{J}$ Watterson Cucurbit diseases. Petoseed. Saticoy, California. 1988: 48.

8. Tewari VP and S Ramanjam Grown Pusa Jawala, a disease resistant high yielding chill: Indian farming. 1974; 24:20-21.

9. Chan P, XU Zhang ZQ, Wang W, Zhu K, Lu GL and H Liu Effects of chemical control of cotton aphid during the early season on vegetables on natural enemies and yield. J Appl Entomol 1991; 111:211-215.

10. Reddy PS and HR Reddy Studied on the transmission of virus in cucumber (Cucurnas salivus L) by M. pcrsicae SIUL. Indian J virol 1991; 7(1): 82-88.

11. Noordam D Identification of plant viruses. Methods and experiments. Oxford and IBH Publishing Co., New Delhi. 1973: 207.

12. Ali S, Khan MA, Habib A, Rasheed S and Y Iftikhar Management of okra YellowVein Mosaic Disease of Okra Through Pesticide/Bio- pesticide and Suitable Cultivars int of agri boil 2005; 7 (1): 145-147.

13. Leicht W lmidacloprid - a chloronicotinyl insecticide biological activity and agricultural significance. Pflanzenschutz Nachrichten Bayer 1993; 49:71-83.

14. Mullins JW lmidaclopnd: A new nitroguanidine insecticide Am Chem Soc Symposium Series 2003; 51:8005-8010.

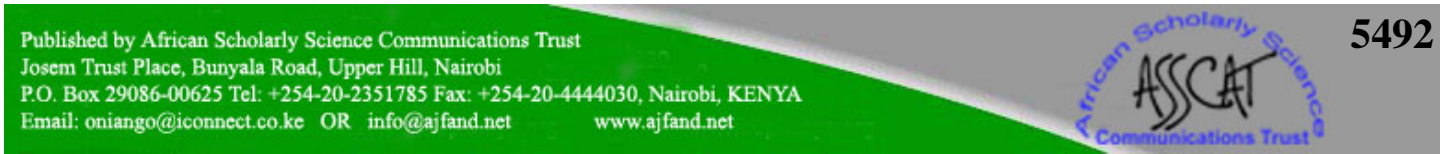


15. Aslam M and SNH Naqvi The efficacy of Phytopesticides in comparison with perfekthion against sucking pests of cotton. Turkish J Zoo 2000; 24(4): 403-408.

16. Gibson RW and AD Rice The combined LISe of mineral oils and pyrethroid to control plant viruses transmitted non- and semipersistently by Mizus persicae. Annals of applied Biology 1986; 109: 465- 472.

17. Thomas $\mathbf{L}$ and BI Murray Insect growth regulating effects of neem extract and azadirachtin on aphids. Entomologia Experimentalis Applicata 1994; 72(1):77-84.

18. Letchoumanane $\mathbf{S}$ and $\mathbf{D}$ Adiroubane Field efficacy of botanical extracts for controlling major pests of okra. Indian J Agric Sci 1998; 68:168-170.

19. Hardie J, Nong G, Timar T, Sebok $\mathbf{P}$ and A Honda Precocenes derivatives and aphid morphogenesis. Arch Insect Biochem Physiol 1996; 32: 493-501.

20. Liu JZ, Richerson K and RS Nelson Growth Conditions for Plant VirusHost Studies. Current Protocols in Microbiology 2009; 14:16A.1.1-16A.1.16.

21. Ashfaq A, Khan MA and N Javed Characterization of environmental factors conducive for urdbean leaf crinkle virus (ULC) disease development. Pak $J$ Bot 2008; 40(6): 2645-2653. 